\title{
Auditor Switching on the Basic Industry and Chemicals Sectors in Indonesia: Whether Influenced Management Change, Company Size, Going Concern Opinion, and Financial Distress?
}

\author{
Arry Eksandy Mulyadi Mohamad Zulman Hakim Hesty Erviani Zulaecha Dewi Rachmania \\ Muhammadiyah University of Tangerang
}

\begin{abstract}
This research aims to analyze the factors which influence the auditor switching on the basic industry and chemicals in Indonesia. The contribution of this research for the management of the company is as input on the policies to be taken up in connection with the implementation of switching Auditors, where as for the auditor or public accountant that is becoming one of the information about the practice of switching Auditors committed companies. Research variables used in this study is the changing of the management (CEO), the size of the company (LnTA), going concern opinion (OGC), financial distress (FD) and auditor switching (SWITCH). Analysis tool used is logistic regression with panel data using program EViews (Econometric Views) version 9.0. The sample of this research is the basic industry and chemicals companies were listed on the Indonesia stock exchange (BEI) in 20112015 amounted to 45 companies that are taken using the method of purposive sampling. The results of this research is to turn management of the positive effect to auditor switching. While the size of the company, opinion going concern and financial distress had no effect to auditor switching.
\end{abstract}

Keywords: Auditor Switching, Management Requirement, Size Company, Going Concern, Opinion, Financial Distress.

DOI: $10.7176 / \mathrm{JESD} / 11-2-14$

Publication date: January $31^{\text {st }} 2020$

\section{Introduction}

The financial statements should be presented by management as a performance management. The financial statements have the possibility for outside interests were interfered corporate interests from the management it self so needed an independent, in this case a public accountant (auditor) to mediate the conflict of interest between shareholders with management companies (Suarjana and Widhiyani, 2015).

The audit opinion is one of the causative factors for the turn of the auditor. The auditor provides the audit opinion through several stages of the audit so that the auditor may give the conclusion over the opinion must be given from the audited financial statements. The expected management opinion are of course unqualified opinion not qualified opinion because it can affect the stock price. Going concern opinion is the opinion of management that is not expected because of the existence of the company risks showed could not survive in his business and could not maintain his survival in the future. Therefore, when auditors provide an opinion not in accordance with the desires, they tend to dismiss Auditors. This is in line with the Wahyuningsih and Suryanawa (2012) stating if the auditor cannot give unqualified opinion (not in keeping with the expectations of the company), the company will move the public Accountant (KAP) which might be able to provide opinion as expected.

This is where the role of the Auditors as the party that expected by the various parties to be able to be independently tested, independence becomes absolute master key must be owned by each auditor while doing their job of judging the fairness of the financial statements of its clients, the independence here means that cannot be influenced by any party (Rahayu, 2012).

The independence of the public accountant (KAP) Auditors will be lost if you have a long relationship with the client causing the entwined relationship more closely between the auditor with the client. According to Wijayani and Januarti (2011) that the long audits Alliance also was believed to be carrying high and dependent consequences can create relationships a strong loyalty and ultimately affect the mental attitude as well as their opinion. So the public accountant or auditor will always favor towards the client, who can reach the stage where the auditor's independence is threatened. Solutions to maintain the independence of the auditor is to do a rotation of public accountant (KAP).

When the auditor first audit of one client, auditors must understand the client's business environment and the risk of an audit client. For auditors who are not at all familiar with the second problem, then start up costs be high so that it can increase the audit fee. In addition, the first assignment is shown to have a high of confusion. This is in line with Aprillia (2013) stating the turn the public accountant (KAP) which will often result in an increase in fee audits.

Turn the auditor usually causes changes in the policies of one such appointment of the KAP as well as a public accountant. This is in line with Susanto (2014) stating that the influx of new people, CEO or Manager, it can be worn as a sign that the old ways need to be changed. 
The size of a large client companies have complex business operations. This will bring the company size impact on the selection of a public accountant in accordance with the size of the client company. This is in line with Suarjana and Widhiyani (2015) stating that large companies have a greater incentive than small companies tend to retain their auditors.

Financial distress is a condition where the company experienced unhealthy conditions or difficulty in finance so feared bankruptcy Dwiyanti and Sabeni (2014). The bankrupt companies are more likely to switch auditors (KAP) from companies not bankrupted Putra (2014). Switching auditors is the turn of KAP Auditors conducted by the company. Auditor switching can be mandatory or voluntary. Switching auditors is mandatory occurs due to implement of the applicable regulatory provisions. While the voluntary switching auditors happened for a reason or there are certain factors of the client company as well as from the KAP outside the provisions of the regulation in force Pawitri and Yadnyana (2015).

The Government of Indonesia through the decision of the Minister of Finance No. 423/KMK. 06/2002 which was changed to the decision of the Minister of Finance No. 359/KMK. 06/2003 requires that the company replace the KAP that has got the audit assignment for five years in a row. Companies that replace the KAP of his already auditing five years will not raise questions because of the displacement of the auditor are mandatory. The regulations are updated regulation of the Minister of Finance of the Republic of Indonesia number 17/FMD. 01/2008 about the "public accounting Services" Chapter 3. These regulations govern the awarding of general audit the financial statements of an entity is done by the KAP of most long for six years of consecutive and berturu book by a public accountant is the longest for three consecutive fiscal year. The problem arises when a company replace the KAP over the wishes of the company itself (voluntary) (Wahyuningsih and Suryanawa, 2012).

The turn of the public accountant (KAP) effected by the auditor and client relationship on the Enron scandal are in the United States in 2001, as a large KAP that fall into the ranks of the world's largest KAP of five. The familiarity of these intertwined relationships cause the KAP of Arthur Andersen engaged in a fraud carried out by its clients Enron so the failed to maintain the independensinya and caused the collapse of the KAP of Arthur Andersen.

While the scandal in Indonesia involving auditor i.e. case company PT Lippo Bank and PT Kimia Farma which do earning management is financial statement on the 31st of Desembes 2001, indicates the existence of a net profit of Rp 132 billion, and the report audited by Hans Tuanakotta Mustofa \& (HTM). However, the Ministry of BUMN and BAPEPAM argued that the net profit is too large and contain elements of engineering. After the audit, done on October 3, 2002 finance report PT. KAEF 2001 year restated (restated). This is due to a fault has been found are pretty basic. On the financial statements restated earnings, which is served only Rp 99.56 billion lower, or Rp 32.6 billion, or $24.7 \%$ of initial profit reported. The emergence of these cases makes the quality of auditing became a very important thing to note, the quality of audits was made auditor of the probability to find and report wrong-food material found on his client's financial reports Arestantya and Wirajaya, 2016).

These cases prove the length of time the Alliance has the power to audit creates closeness between auditors with clients. This resulted in a decline in the attitude of independence which should be owned by the Auditors and the audit quality reduced impact and cause public distrust toward the profession of Accountants because it gives the implication that large KAP violated the integrity, objectivity, and independence. Therefore, it is the turn of auditors is aimed at safe guarding the independence of the auditor to be objective in performing his duties as auditor Pawitri and Yadnyana (2015).

This research was conducted, to re-test the factors used in previous research using the dimensions of time, place, and a different proxy so that it can find the empirical evidence, because previous research results always showed different results or research GAP.

\section{Theory Review}

\subsection{Agency Theory}

Theoretical evidence regarding switching auditors is based on the theory of agency. Agency theory developed by Jensen and Meckling (1976) stated the agency problem caused by the existence of a conflict of interest and information asymmetry between principal and agent. In the study putra (2011) there are three conflicts of interest: (1) between shareholders and managers, (2) between the shareholders and debtholders, and (3) between the managers, shareholders, debtholders and. Conflict of interest between the owner and the agent likely occurred because the agent is not always done in accordance with the interests of the principal, so the trigger agency fee (agency cost), the level of these costs varies on the organization, depending on variables such as the size of the company, and management's share ownership. Turn management generally applying the new accounting method so that new management could expect more cooperation with KAP replacement and hope would later get the opinion in accordance with the wishes of the management which are then encouraged to suggest management in general meeting of shareholders to replace public accountant (KAP). In theory this agency, the independent auditor acts as the mediator of both parties (the agent and principal) of different interests, independent Auditor also serves to reduce the cost of the Agency arising from the self-serving behavior by agents (abdilah, 2013). Agency theory 
suggests that the managing of acting on its own interests rather than the interests of the investors as the legitimate owners of the company. This will establish the existence of the protection of the interests of shareholders and creditors as opposed to an jujuran done management. According to Widiawan (2011) the Auditor has an important role as a liaison between the company (management) and its shareholders. Audit financial reports expected can truly reflect the company's true condition and information distributed to the public must be sincere, the integrity and timely (budi; arifati; oemar, 2015). Theoretical evidence regarding substitution of Auditors is based on the theory of Agency. Either principal or agent want to benefit most and want to avoid the risk that may occur within the company. In the theory of Agency, independent auditor acts as the mediator of both parties (the agent and principal) of different interests.

\subsection{Auditor Switching}

Auditor Switching is the displacement of the auditor or the KAP is done by the client company. This can be caused by factors or factor client auditor Juliantari and Rasmini (2013). Switching Auditors is mandatory in turn of the auditor who performed the company because of the regulations requires that the company replace the Auditors within a certain period. In contrast, the voluntary switching Auditors is an act committed the company to change Auditors when there is no rule that requires it to change Auditors. Juliantari and Rasmini (2013) are two factors that can affect a client replace Auditors is Auditors factor because the quality and fee, whereas the client factors due to changes ownership, financial distress, IPO (Initial Public Offering) and management that failed. The independence of the public accountant (KAP) Auditors will be lost if you have a long relationship with the client causing the entwined relationship more closely between the auditor with the client. Switching auditors need to be done by the company to maintain the independence of the auditor. Appropriate regulation of the Minister of Finance the Republic of Indonesia number 17/FMD. 01/2008 about the "public accounting Services" Chapter 3. These regulations govern the awarding of general audit the financial statements of an entity is done by the KAP of most long for six years of consecutive and by a public accountant is the longest for three consecutive yearbook.

\subsection{Management Change}

Dwiyanti and Sabeni (2014) stated that the influx of new people, CEO or Manager, it can be worn as a sign that the old ways need to be changed. With a turnover in management, would likely change occurred due to the issuance of new policies, one turn of the auditor (auditor switching). Pradhana and Saputra (2015) States turn ordinary management carried out by big companies that go-public. Management turnover is done by looking at the condition of the company's existing management structure which turned out to be incapable of managing the company well. The turn of the public accountant is defined as whether or not there is the turn of public accountant activity conducted by the company's clients (auditees).

\subsection{Company Size}

Rahayu (2012) size of company can be expressed in total assets, sales and market capitalization. The greater the total assets, sales and market capitalization then the greater the size of the company anyway. The greater the more capital assets that were planted. The more sales the more turnover and the greater market capitalization then the bigger companies are known in the community so that companies can afford to use the services of a qualified auditor (KAP) of the greater, in addition to getting a quality audit results, using the services of a reputable auditor will raise the prestige of the company will be good in the eyes of stakeholders. Sidhi and Wirakusuma (2015) of the larger client companies have business complexity and increased separation between ownership and management, due to the size of the client company increases of conflict inflated so that agents are also increased the demand for quality audit. Ideally the size of company audit should correspond to the size of the client company and the type of service required. The increase in the size of the company will increase the number of agency relationships, it will complicate the company's owners to monitor the actions of opportunistic management. A solution can be reached in this situation is to replace an auditor with a more independent auditors in order to control the risks.

\subsection{Going Concern Opinion}

The audit opinion is defined as statements of opinion given by the auditor in assessing the reasonableness of the company's financial statements agreement in the audit (Rahayu, 2012). In the public accounting Profession Standards (2011) explained that the purpose of auditing financial statements by an independent auditor to express an opinion on the reasonableness of all material things, business results, financial position, change in equity, and cash flows in accordance with generally accepted accounting principle in Indonesia. Going concern opinion is an opinion issued by an auditor to ascertain whether the company can sustain life. Researchers accounting and financial reporting users in particular considers an opinion going concern as a warning that the financial distress faced by the client the client will direct the auditor to perform prevention of bankruptcy Wahyuningsih and Suryanawa (2012). The receipt of an audit opinion going concern is very useful for users of financial statements 
to make proper decisions in investing. It is important because when an investor will undertake the investment necessary to know the financial condition of the company, especially regarding business continuity Wahyuningsih and Suryanawa (2012).

\subsection{Financial Distress}

Financial distress is a condition where the company experienced unhealthy conditions or difficulty in finance so feared bankruptcy (Sabeni, 2014). Management is often faced with failure in raising company. Due to survival (going concern) the company's future is not clear. The company is not healthy or sick, even sustained a prolonged crisis. This condition can lead to bankruptcy or liquidation or towards insolvabilitas. Insolvency (bankruptcy) is defined as the failure of the company in operating the company to generate profit (Supardi and Mastuti in Rahayu, 2012). KAP schwartz and soo in Astrini and Muid (2013) stated that the bankrupt company more often move the KAP than companies that didn't go bankrupt. Uncertainty in business companies that threatened to bankrupt (having financial distress) cause the conditions that encourage companies switch KAP.

\section{Research Methods}

\subsection{Population and Sample}

The population used in this research is the basic industry and chemical sectors listed in Indonesia stock exchange of the year 2011-2015 with the amount of as much as 65 companies with sample withdrawal technique used is the purposive sampling. retrieved 9 companies that comply with the criteria sampling of the years 2011 to 2015 with or for 5 years so observations obtained is as much as 45 observations is used as a source of data to be analyzed.

\subsection{Definitions and Operational Variables}

1) Management Change

Management Change is when companies replace their CEO or Board of Directors. This research uses a dummy variable. If there is a substitution of the management of the company, then it is given a value of 1 . Whereas if there is no turn management then is given the value 0 (Aprillia 2013).

2) Company Size

Size large small companies seen from assets owned by the company. the greater the total asset owned by the company then that company size is so large and vice versa. The size of the company is calculated by taking the total assets of the company Ln Total Assets (Wijayani and Indira, 2011).

Total Asset $=$ Aktiva Lancar + Aktiva Tetap

\section{3) Going Concern Opinion}

Going concern opinion issued by the Auditors in which an auditor is experiencing doubt the ability of entities in maintaining his survival. The measurement of this variable is a dummy variable. If the company gets the opinion of going concern given the mark 1 and if it does not get the opinion of going concern given the sign of 0 (Wijaya and Rasmini, 2015).

4) Financial distress

Financial distress is where the company was having financial distress. Putra and Suryanawa (2016) measurement of the Financial distress using the formula:

$$
\text { Debt to Equity Ratio }(D E R)=\frac{\text { Total Liability }}{\text { Total Equity }}
$$

5) Auditors Switching

Auditor switching is the turn of KAP. The auditor switching intended in this research is the turn of public accounting is done by companies that are voluntary. This research uses a dummy variable. If companies do turn of the public accountant, coded 1 and if not, coded 0 (Wahyuningsih and Suryanawa, 2012).

\subsection{Data collection Techniques}

In this study data used are secondary data. Secondary data is data taken from the source both or not from the original source. These secondary sourced data on annual financial reports published basic industry and chemical sectors registered in BEI 2011-2015 in the period, the data is retrieved from the website http://www.idx.co.id.

3.4 Data analysis techniques

Analytical tools used in this research is the logistic regression analysis (logistic regression). The reason to use the analysis tool because the dependent variable using a dummy variable (Rudyawan \& Badera in Wijaya and Rasmini, 2015). 


\subsection{Descriptive Statistics Analysis}

Descriptive statistics give an overview or description of a data seen from the average (mean), standard deviation, minimum, maximum, variants, sum, range, kurtosis, and skewness (Winarno, 2015). Descriptive analysis is intended to provide an overview or description of the dependent variable in the form of the data of auditor switching, as well as the independent variable in the form of management requirement, size of company, opinion going concern and financial distress in the basic industry and chemical sector registered in BEI 2011-2015 period. 1) Likelihood Ratio Test

Likelihood Ratio Test is used to see the influence of the variable variable bound against free simultaneously. The statistics used are based on the likelihood function. Likelihood L of the model is the probability that the model that illustrates hypothesized input data. To test the hypothesis of zero and an alternative, transformed into L-2LogL. Statistics-2LogL is sometimes called a likelihood ratio $\chi 2$ statistic, where the $\chi 2$ distribution with a degree of freedom, $\mathrm{n}-\mathrm{q}, \mathrm{q}$ is the number of parameters in the model. Statistics-2LogL can also be used to determine if the free variables in the model are added to significantly improve the model fit. Difference-model 2 LogL with constants only and $2 \operatorname{LogL}$-for models with variable constants and freely distributed as $\chi 2$ with df (difference df both models). The model is already a fit if a change-2log likelihood significant (significance $<0.05$ ).

2) Coefficient of Determination

The coefficient of determination R-squares with dinotasikan which is an important measure in the regression, because it can inform good or whether the regression model terestimasi. The value of the coefficient of determination reflects the extent of the variation of the variable can be explained by the variable free. When the value of the coefficient of determination is equal to 0 , which means that the variation of the bound variables can not be explained by its free variables at all. If the value of the coefficient of determination is equal to 1 , which means that the variable is bound to the overall variation can be explained by its free variables. Thus the good or bad of a regression equation determined by R-squares that have a value between zero and one. At the output of the Eviews provided McFadden R-squares as a measure of all R-squares (Ghozali and ratmono, 2013).

3) Partial Test

Partial test done to test the influence of each independent variable the dependent variables against partially or to know which free variables had the most influence on the bound variables. This test is similar to the t-test on multiple linear analysis. The value of this test can be seen in the value of $\mathrm{z}$ or when using the p-value can be seen on items sig (Gujarati in Sendy dkk, 2015). Decision making criteria by using $\alpha=0.05$, namely:

a) If p-value $<0.05$, mean $\mathrm{H} 0$ is rejected and accepted, meaning there is Ha influence between independent variables the dependent variables against

b) If p-value $>0.05$, mean $\mathrm{H} 0$ is accepted and Ha was rejected, meaning that there is no influence between independent variables the dependent variables against.

\section{Research Results and Discussion}

4.1 Statistic Descriptive

Table 1

Statistic Descriptive Analysis

\begin{tabular}{||cccccc|}
\hline & SWITCH & CEO & LNTA & OGC & FD \\
\hline \hline Mean & 0.311111 & 0.422222 & 13.21222 & 0.177778 & 1.805778 \\
Median & 0.000000 & 0.000000 & 13.45000 & 0.000000 & 0.530000 \\
Maximum & 1.000000 & 1.000000 & 14.67000 & 1.000000 & 11.25000 \\
Minimum & 0.000000 & 0.000000 & 11.74000 & 0.000000 & 0.040000 \\
Std. Dev. & 0.468179 & 0.499495 & 0.878402 & 0.386646 & 2.464961 \\
Observations & 45 & 45 & 45 & 45 & 45 \\
\hline
\end{tabular}

Source: Data processed

Based on the above table it can be seen the variable SWITCH had the lowest value 0 to a company that does not do the auditor switching and highest 1 i.e. for companies that perform switching Auditors, mean 0.470 .31 , and standard deviation. The mean value of 0.31 , it does show that as many as $31 \%$ of companies conducting auditor switching and $69 \%$ is not doing the auditor switching. The CEO'S variable (changing of management) have the lowest value 0 to a company that does not do the highest management and turnover 1 i.e. for companies doing turnover of management, mean and standard deviation 0.420 .50 . The mean value of 0.42 , it does show that as many as $42 \%$ of companies doing turnover of management and $58 \%$ did not do turn of the management. LnTA variables (the size of the company) had the lowest value 11.74 namely PT. Intan Wijaya International and highest 14.67 i.e. Keramika PT Indonesia Associated 13.21, the mean and standard deviation 0.88 . Values above $100 \%$ 13.21 mean this means explaining the company taken in sample a lot more big companies. OGC variables (Opinion Going Concern) have the lowest value 0 to companies that do not get the opinion of going concern and highest 1 i.e. for companies that get the opinion of going concern, the mean and standard deviation of 0.180 .39 . The mean 
value of 0.18 , this indicates that as much as $18 \%$ of companies receiving opinions going concern and $82 \%$ of companies do not accept the opinion of going concern. The variable FD (Financial Distress) has the lowest value 0.04 namely PT. Indonesia Rachmat Basuki Paper and highest 11.25 namely PT. Tirta Mahakam, the mean and standard deviation 1.812 .46 . Values above $100 \% 1.81$ mean it means the average company was experiencing financial distress.

\subsection{Likelihood Ratio Test}

Table 2.

Likelihood Ratio Test

\begin{tabular}{|c|c|c|c|}
\hline $\begin{array}{l}\text { LR statistic } \\
\text { Prob(LR statistic) }\end{array}$ & $\begin{array}{l}13.42895 \\
0.009359\end{array}$ & Avg. log likelihood & -0.470776 \\
\hline
\end{tabular}

Source: Data processed

In the table above shows the value of LR Statistic probability value 13.42895 (LR Statistic) of 0.009359 . Probability value (LR Statistic) indicates a value smaller than 0.05 the zero hypothesis then rejected. Thus, with 95 per cent confidence level can be inferred that the LNTA, OGC, CEO, FD effect significantly to SWITCH so in other words the hypothesized model fit the data.

4.3 Coefficient of Determinations

Table 3.

Coefficient of Determinations

\section{McFadden R-squared}

0.240667

Source: Data processed

In the table above shows the value of McFadden's R-squared is 0.240667 . These results show that the variability of the dependent variable (the auditor switching) that can be explained by the independent variables (company size, management requirement, opinion going concern and financial distress) amounted to $24.07 \%$ while the rest of $75.93 \%$ explained by variables other than this research model.

\subsection{Partial Test}

Table 4.

Partial Test

\begin{tabular}{|crrrc|}
\hline Variable & Coefficient & Std. Error & z-Statistic & Prob. \\
C & 3.028732 & 3.893497 & 0.777895 & 0.4366 \\
CEO & 2.466846 & 1.116634 & 2.209180 & 0.0272 \\
LNTA & -0.454829 & 0.301640 & -1.507853 & 0.1316 \\
OGC & 1.087171 & 0.971180 & 1.119433 & 0.2630 \\
FD & -0.065052 & 0.174172 & -0.373493 & 0.7088 \\
\hline
\end{tabular}

Source: Data processed

Four variables are included in the regression in the table above there is 1 positive effect variables against auditor switching is turn management (CEO) and the level of significance (0.027) smaller than $\alpha(0.05)$, whereas the size of the company (LnTA) with a level of significance of 0.132 , going concern opinion (OGC) with a level of significance of 0.263 and financial distress (FD) with the level of significance of 0.709 has a value greater than 0.05 which means no effect against switching Auditors. The results of the calculations contained in the Partial-test indicates that there is only one variable that influence positively against auditor switching, i.e. turnover management. While the size of the company, opinion going concern and financial distress had no effect against the auditor switching. The research of the regression equation, which is formed are as follows:

$\mathrm{Ln}=\frac{\mathrm{P}(\text { SWITCH })}{1-\mathrm{P}(\text { SWITCH })}=3,029+2,467 \mathrm{CEO}-0,454 \mathrm{LnTA}+1,0870 \mathrm{GC}-0,065 \mathrm{FD}$

The above regression model means that the constants of 3.029 showed that if the variable management requirement, size of company, opinion going concern and financial distress is considered constant then the average occurrence of auditor switching on the basic industrial sectors manufacturing company and chemistry as much as 3.029. The regression coefficient of turnover of 2.467 management showed that every occurrence of succession management potentially increase the occurrence of auditor switching as much as 2.467 . The regression coefficient of the size of the company amounting to 0.454 indicates that any decrease in the size of the company reduce auditor 
switching as much as 0.454 . The regression coefficient of opinion going concern of 1.087 indicates that any acceptance of opinions going concern increasing occurrence of auditor switching as much as 1.087 . The regression coefficient of the financial distress of 0.065 showed that any decline in financial distress reducing auditor switching as much 0.065 .

\subsection{Discussion}

1) Management Requirement to Auditor Switching.

The first hypothesis is proposed in this study was the turn of positive effect against management auditor switching. From the results of this research obtained regression coefficient values for the variables of management turnover of 2.467 with a level of significance of 0.027 smaller than $\alpha(0.05)$. Because of significant value $(0.027)<\alpha(0.05)$, it can be concluded that the first hypothesis was accepted, meaning that management requirement positive effect against auditor switching. Thus, the more frequently the companies doing turnover of management or Director (CEO), then it will be more of such companies often do auditor switching. These results fit with research results Pawitri and Yadnyana (2015) and Suryanti (2015) stating that management turnover became one of the causes he did, auditor switching.

2) Company Size to Auditor Switching.

The second hypothesis proposed in this research is a measure of the company's positive effect against auditor switching. From the results of this research obtained regression coefficient values for the variable size of companylevel 0.455 significance of 0.132 greater than $\alpha(0.05)$. Because of significant value $(0.132)>\alpha(0.05)$, it can be concluded that the second hypothesis is rejected, meaning that the company's size has no effect against the auditor switching. The results of this study in accordance with the Suarjana research and Widhiyani (2015) and Suryanti (2015) which found that large companies have used the Auditors are great so there is no need to replace Auditors, while small companies still use KAP and haven't felt the need to replace the KAP.

3) Going Concern Opinion to Auditor Switching.

The third hypothesis proposed in this research are opinions going concern a positive effect against switching Auditors. From the results of this research obtained regression coefficient values for the variable opinions going concern of significance level of 1.0870 .263 greater than $\alpha(0.05)$. Because of significant value $(0.263)>\alpha(0.05)$, it can be concluded that the third hypothesis is rejected, meaning opinion going concern has no effect against the auditor switching. The results of this study are in line with research Wahyuningsih (2012) and Meryani (2013) showed that even though the publishing company received opinion going concern but the company doesn't do turn of the auditor because although the company replace a corporate auditors, if the condition is indeed being no good, then the same opinion also is likely to come by the company of the other auditors.

4) Financial distress to Auditor Switching.

The fourth hypothesis proposed in this study is financial distress a positive effect against switching Auditors. From the results of this research obtained regression coefficient values for variable financial distress of 0.065 -with a level of significance of 0.709 greater than $\alpha(0.05)$. Because of significant value $(0.542)>\alpha(0.05)$, then it can be inferred that the fourth hypothesis is rejected, meaning that financial distress had no effect against the auditor switching. The research was supported by the results of the research conducted and Similarly S (2015) which found that companies in financial distress conditions tend not to perform the auditor switching possibility due to substitution of Auditors at the company that too often will increase the audit fee.

\section{Conclusions, and Suggestions}

\subsection{Conclusions}

Based on the research results obtained by testing statistics and discussion as has been outlined in previous chapters then it can be inferred that:

1) The level of significance is the management of turnover $(0.027)<\alpha(0.05)$. the Results show that the positive effect of management requirement against auditor switching, which means changing of management in the company is often followed by a policy change in the company, because the new management brought new policies and regulations to support the policy. One of those changes may be on the selection of hood.

2) The Level of significance of the size of the company is as big $(0.132)>\alpha(0.05)$. The results showed that the company's size has no effect against the auditor switching, which might be due to the large companies have used the Auditors are great so there is no need to replace Auditors, while small companies still use KAP and haven't felt the need to replace her KAP.

3) Level of significance going concern opinion is registration $(0.263)>\alpha(0.05)$. The results show that opinion going concern has no effect against switching Auditors, showed that even though the publishing company received opinion going concern but the company doesn't do turn of the auditor because although the company replace a corporate auditor, if the condition is indeed being no good, then the same opinion also is likely to come by the company of the other auditors.

4) Level of significance financial distress is registration $(0.542)>\alpha(0.05)$. The results show that financial distress 
had no effect against the auditor switching, which might be due to companies in financial distress conditions tend not to perform Auditors switching because the turn of Auditors at the company that too often will increase the audit fee or perhaps the company has used the Auditors judged worthy to audit the company though financial distress level increases.

\subsection{Suggestions}

Here's some advice based on the results of the research have been obtained:

a) To research the next expected sample used not only the basic industrial sector manufacturing company and chemistry alone would be better if the sample coupled with some sectors the company because in the basic industrial sector manufacturing companies and chemical company, which receives very little going concern opinion.

b) For subsequent research is expected to be able to add other variables that have not been raised in this study that may explain the dependent variables with higher variability.

c) For subsequent researchers in search of corporate financial report data and independent auditor's report which is not presented on the website http://www.idx.co.id, should look for on the company's website is needed as well.

\section{References}

Aprillia, Ekka. 2013. Analisis Faktor-Faktor Yang Mempengaruhi Auditor Switching. Accounting Analysis Journal. (ISSN 2252-6765).

Arestantya, dkk. 2016. Ukuran Kantor Akuntan Publik Sebagai Pemoderasi Pengaruh Auditor Switching pada Kualitas Audit. E-Jurnal Akuntansi Universitas Udayana. (Vol.15; No.2; hal 1228-1254).

Astuti, Ni Luh Putu dan I Wayan, Ramantha. 2014. Pengaruh Audit Fee, Opini Going Concern, Financial Distress dan Ukuran Perusahaan Pada Pergantian Auditor. E-Jurnal Akuntansi Universitas Udayana. (Vol. 7; No.3; hal 663-676).

Ghozali, Imam. 2014. Aplikasi Analisis Multivariate dengan Program SPSS. Semarang ; Badan penerbit Universitas Diponegoro.

Ghozali, Imam dan Ratmono. 2013. Analisis Multivariat dan Ekonometrika, Teori, Konsep, dan Aplikasi dengan Eviews. Semarang : Badan Penerbit Universitas Deponegoro.

Gunady, Filani dan Yenni, Mangoting. 2013. Faktor-Faktor yang Mempengaruhi Keputusan Perusahaan Manufaktur yang Terdaftar di BEI Tahun 2008-2012 Melakukan Pergantian Kantor Akuntan Publik. Tax dan Accounting Review. (Vol. 3; No.2, 2013).

Institut Akuntan Publik Indonesia. 2011. Standar Profesi Akuntansi Publik.. Jakarta; Salemba Empat.

Juliantari , Ni Wayan Ari dan Ni Ketut Rasmini. 2013. Auditor Switching dan Faktor-Faktor Yang Mempengaruhinya. E-Jurnal Akuntansi Universitas Udayana. (Vol 3; No.3; hal 231-246).

Kartika, Andi, 2009. Faktor-faktor Yang Mempengaruhi Audit Delay di Indonesia. Jurnal Bisnis dan Ekonomi (JBE). (ISSN: 1412-3126 hal. 1-17)

Pawitri, Ni Made Puspa dan Ketut Yadnyana. 2015. Pengaruh Audit Delay, Opini Audit, Reputasi Auditor dan Pergantian Manajemen Pada Voluntary Auditor Switching. E-jurnal Akuntansi Universitas Udayana. (Vol.10; No.1; hal 214-223).

Pradhana, Made Aditya Bayu dan Suputra, I.D.G. Dharma. 2015. Pengaruh Audit Fee, Going Concern, Financial Distress, Ukuran Perusahaan, Pergantian Manajemen Pada Pergantian Auditor. E-Jurnal Akuntansi Universitas Udayana. (Vol.3; No.3: hal 231-246).

Putra, I Wayan. 2014. Pengaruh Financial Distress, Rentabilitas, Pertumbuhan Perusahaan, dan Opini Audit Pada Pergantian Manajemen. E-Jurnal Akuntansi Universitas Udayana. (Vol. 8; No.2; hal 308-323).

Putra, I Gusti dan I Ketut, Suryanawa. 2016. Pengaruh Opini Audit dan Reputasi KAP Pada Auditor Switching Dengan Financial Distress sebagai Variabel Moderasi. E-Jurnal Akuntansi Universitas Udayana. (Vol. 14; No.2; hal 1120-1149).

Rahayu, dkk. 2013. Auditing Konsep Dasar dan Pedoman Pemeriksaan Akuntan Publik. Jogyakarta : Graha Ilmu. Rianse. 2012. Metodologi Penelitian Sosial dan Ekonomi. Bandung : Penerbit Alfabeta.

Setiawan, I Made dan Aryani, M. 2014. Pengaruh Corporate Social Responsibility, Auditor Opinion, Financial Distress dan Accounting Firm Size Pada Auditor Switching. E-Journal Akuntansi Universitas Udayana. (Vol 8; No.3; hal 423-441).

Sidhi, Bagus Ananta dan Wirakusuma. 2015. Pengaruh Ukuran Perusahaan, Tingkat Penjualan dan Reputasi KAP Pada Pergantian KAP. E-Jurnal Akuntansi Universitas Udayana. (Vol.13; No.3, hal 723-736).

Slat, Andre Henri, 2013. Analisis Harga Pokok Produk dengan Metode Full Costing dan Penentuan Harga Jual. Jurnal EMBA.(Vol. 1: No.3 hal 110-117).

Suarjana, I Wayan dan Ni Luh Sari Widhiyani. 2015. Faktor Klien Yang Mempengaruhi Pergantian Kantor Akuntan Publik di Bursa Efek Indonesia. E-Jurnal Akuntansi Universitas Udayana. (Vol. 10; No.1; hal 78- 
90).

Wahyuningsih, Nur dan I Ketut Suryanawa. 2012. Analisis Pengaruh Opini Audit Going Concern dan Pergantian Manajemen Pada Auditor Switching. Jurnal Ilmiah Akuntansi dan Bisnis.

Wijaya, Edwin dan Ni Ketut, Rasmini. 2015. Pengaruh Audit Fee, Opini Going Concern, Financial Distress, Ukuran Perusahaan, Ukuran KAP Pada Pergantian Auditor. E-Jurnal Akuntansi Universitas Udayana. (Vol. 11; No.3; hal 940-966).

Winarno, Wing Wahyu. 2015. Analisis Ekonometrika dan Statistika dengan Eviews. Yogyakarta: UPP STIM YKPN.

www.idx.co.id 